\title{
Degradation of Mangrove Leaf Litter by the Tropical Sesarmid Crab Chiromanthes onychophorum
}

\author{
D.F. Malley \\ School of Natural Resources, University of Michigan; Ann Arbor, Michigan, USA, and School of Biological Sciences, Universiti Sains Malaysia; \\ Penang, Malaysia
}

\begin{abstract}
In high-diversity tropical mangrove swamps, the relationship between the breakdown to detritus of mangrove plant litter and secondary production of associated estuaries is little understood. This study examined one step in this relationship, the breakdown of mangrove leaf litter to detrital-sized particles by the sesarmid crab Chiromanthes onychophorum, locally very abundant in mangrove swamps of peninsular Malaysia. Contents of the proventriculus (stomach) and of the posterior hindgut, including rectum, were analyzed and particle sizes were measured. Gut contents consisted of more than 95 응 volume of mangrove leaf fragments. Particles in the hindgut were of smaller mean size than those in the proventriculus. It is concluded that $c$. onychophorum consumes fallen leaves or their fragments, incompletely digests them, and returns them to the environment as fecal matter in a more finely-divided state than when they were ingested. C. onychophorum may therefore be a significant agent of mangrove leaf degradation to detrital-sized particles in swamp areas where it is abundant.
\end{abstract}

\section{Introduction}

It is increasingly recognized that coastal and estuarine food chains are based to a significant extent on detritus and dissolved organic matter produced from the breakdown of rooted and attached macrophytes of intertidal and shallow subtidal habitats (Darnell, 1967a, b; Mann, 1972a). Consequently, degradation of macrophytes of kelp beds (Mann, 1972b), Spartina sp. salt marshes (Teal, 1962; Odum and de la Cruz, 1967) and Thalassia sp. turtle grass beds (Fenchel, 1970) has been a topic of much recent study.

In the tropics and subtropics, a dominant intertidal vegetation type is the mangrove swamp (Walsh, 1974). The few estimates of net primary productivity available for these swamps (Golley et al., 1962; Heald, 1971) suggest that it is three to four times greater on an areal basis than that of coastal phytoplankton (Mann, 1972a). Iittle of the standing mangrove biomass is grazed, and most of the biomass is therefore available to the decomposers and detritus-consumers both within the swamp and in adjacent waters (Heald, 1971). In Florida (USA) estuaries, detritus derived from mangrove-swamp macrophytes is an important food item of some commercial or edible species such as the striped mullet Mugil cephalus, penaeid shrimps, mussels and other bivalves, or alternatively serves as food for prey species of many important game fishes which use the estuaries (Odum 1971). Most of the information on the ecology of mangrove swamps has come from studies on low-diversity subtropical swamps. It may not accurately reflect the dynamics of the much more diverse tropical swamps, where far-reaching management and land-use decisions are currently being made. For example, the swamp in Florida studied by Heald (1971) consisted of 2 species of mangroves whereas peninsular Malaysian swamps have 40 species (Watson, 1928). Further, leaf-litter breakdown rates in a Malaysian swamp were found to be 10 times faster (Mathias, 1975) than those in the Florida swamp (Heald, 1971). The present study was initiated to examine one of the steps in the detritus food chain linking primary production of a tropical mangrove swamp to production of coastal fisheries. In the Indo-Pacific region, sesarmid crabs are abundant 
and conspicuous members of the surface and infauna of these swamps and Chiromanthes onychophorum De Man, 1895 is the most abundant sesarmid crab on the forest floor in certain swamps in Malaysia (Berry, 1972). Macnae (1968) reports that sesarmids chop up and consume fallen mangrove leaves, and he speculated that this may be related to the scarcity of the leaf litter on the forest floor. This paper provides evidence that the sesarmid crab $C$. onychophorum (Brachyura: Grapsidae: Sesarminae) is a significant agent in the breakdown of mangrove leaf litter to detrital-sized particles. This was determined by examining gut contents to infer types of food eaten and their condition when released back into the environment as fecal matter.

\section{Materials and Methods}

\section{Collecting Sites and Procedures}

Chiromanthes onychophorum were collected from a disturbed mangrove swamp on the west coast of Penang Island, West Malaysia, at $5^{\circ} 24^{\prime} 30^{\prime \prime} \mathrm{N} ; 100^{\circ} 10^{\prime} 30^{\prime \prime} \mathrm{E}$, near Pantai Acheh village (Fig. 1). During the 3-month period (August to October, 1974) when collections were made in this swamp, portions of it were in the early stages of reclamation. The collecting sites other than site 3 were not directly affected, and all were subject to normal tidal inundation.

Three sites were selected. Site 1 was an open, regenerating stand dominated by Avicennia intermedia trees of about 8 to $10 \mathrm{~m}$ height. About $95 \%$ of the trees were of this species, the remainder being largely young Bruguiera caryophylloides about 3 to $5 \mathrm{~m}$ high. $A$. intermedia seedlings grew abundantly on the swamp floor. Site 2, $450 \mathrm{~m}$ inland of site 1, was a more mature stand in which $A$. intermedia trees, mostly about 12 to $14 \mathrm{~m} \mathrm{high,}$ some $20 \mathrm{~m}$, constituted $70 \%$ of the trees. $B$. caryophylloides of up to $7 \mathrm{~m}$ height was the next most abundant tree species, and Acanthus sp. was also present. Site 3 was in a cleared area $300 \mathrm{~m}$ inland of site 2 where the dominant vegetation before clearing had been the nipa palm Nypa fruticans. These collecting sites were within $1 \mathrm{~km}$ of the seaward side of the swamp. Air temperature at the time of collection, during mid-day or afternoon, varied between $28.5^{\circ}$ and $31^{\circ} \mathrm{C}$. Temperature of standing pools of surface water varied from $27^{\circ}$ to $28^{\circ} \mathrm{C}$, and salinity was 10 to $11 \%$ at sites 1 and 2 , and 2 to $5 \%$ at site 3 . Tree species were identified using Watson (1928). B. caryophylloi-

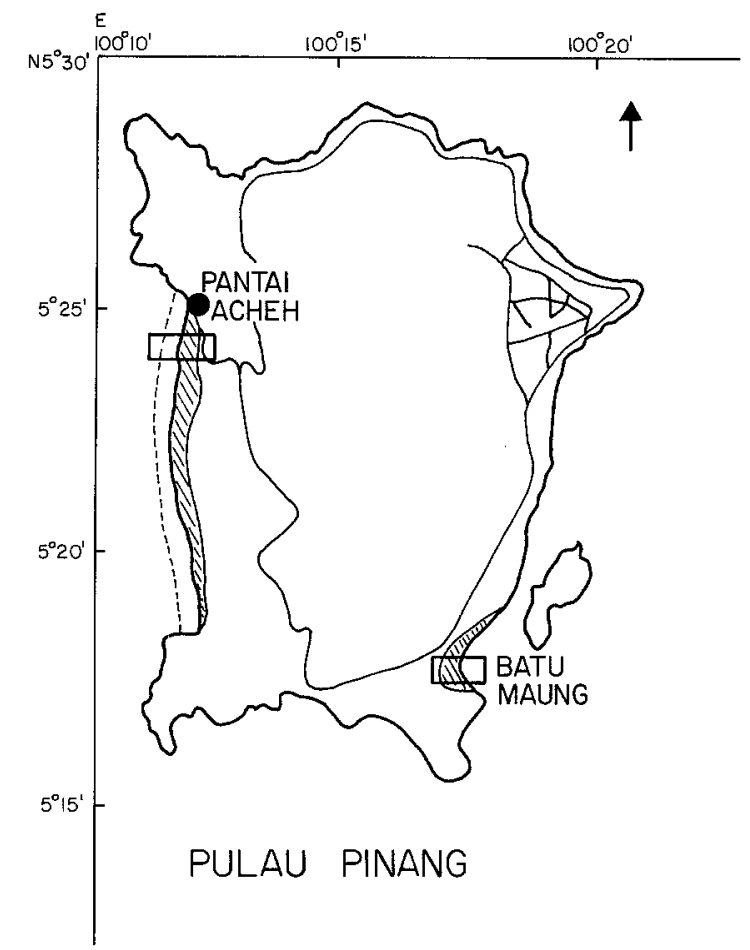

Fig. 1. Map of Penang Island, West Malaysia showing mangrove swamps as cross-hatched areas. Site of this study was the rectangular area adjacent to Pantai Acheh. Pantai Acheh and Batu Maung are villages; broken line off west coast indicates extent of mud flats exposed at low tide

des is synonymous with $B$. cylindrica, Avicennia intermedia with $A$. marina.

For gut content studies, Chiromanthes onychophorum were collected from the swamp floor at Sites 1 and 2, where it was the dominant crab species in its size range. Within minutes of capture, crabs were injected in the field with $20 \%$ formalin solution in sea water neutralized with hexamine and were later stored in 5\% neutralized formalin. Samples of leaves, bark and pneumatophores of the dominant vegetation were collected at the same time as the crabs, and scrapings were taken from the upper few millimeters of the mud. Formalin was added to the mud samples within a few hours of collection. For determination of organic content of gut contents and mud, crabs were collected from sites 2 and 3 and mud samples were taken from the upper 1 to $2 \mathrm{~cm}$ of the mud surface. Crabs were brought back to the laboratory alive and preserved there in formalin.

Chiromanthes onychophorum was identified to genus after Serene and Soh (1970) and to species using the zoological Reference Collection of the Department of $\mathrm{ZO}$ ology, University of Singapore. 

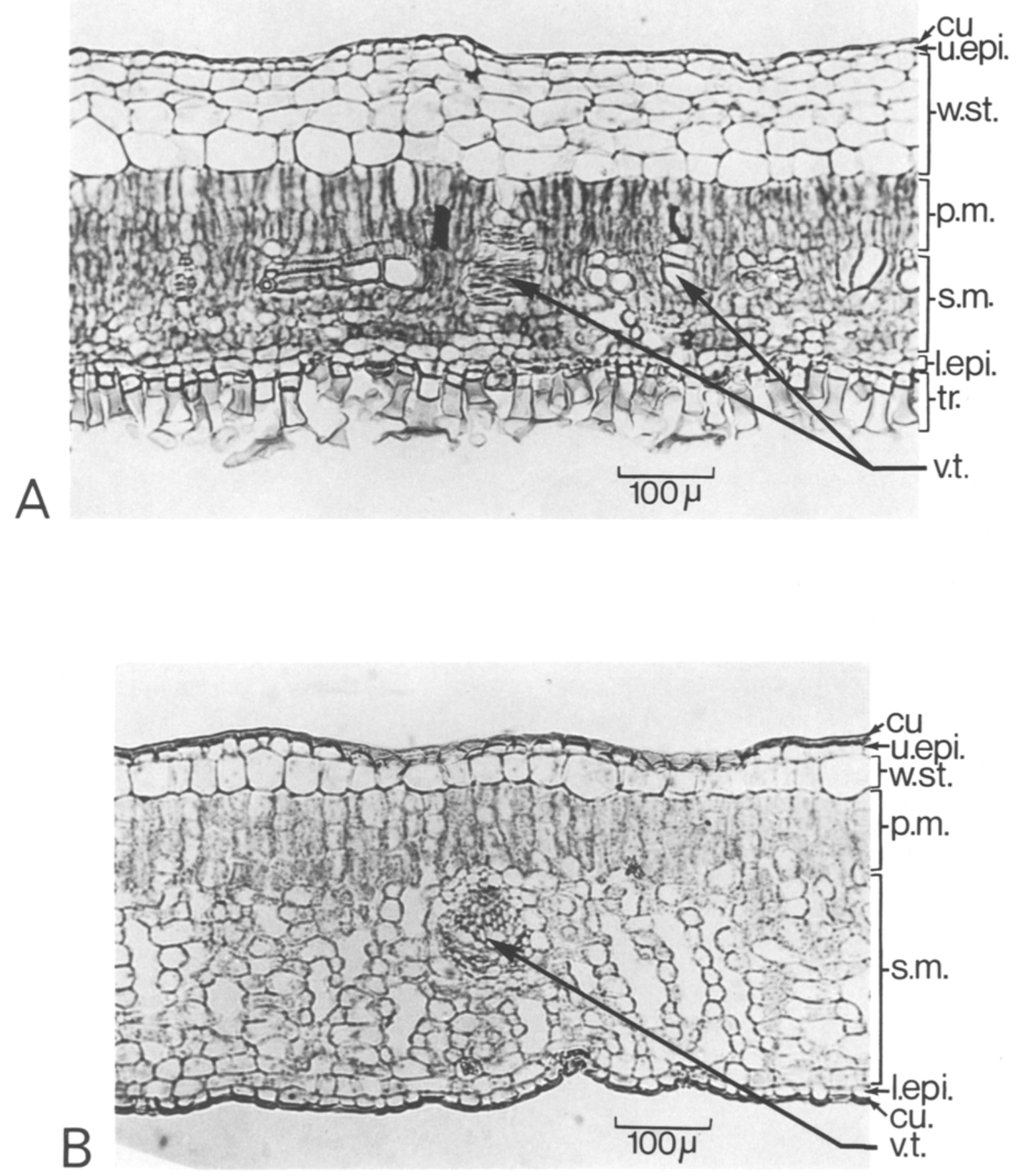

Fig. 2. Cross-sections of leaves (A) Avicennia intermedia, showing upper epidermis (u.epi.) covered by cuticle (cu); main layers are an upper water-storage tissue (w.st.), palisade mesophyll (p.m.), and a lower spongy mesophyll (s.m.); vascular tissue (v.t.) is present in the spongy mesophyli and the lower epidermis of the leaf (l.epi.) is completely covered by closely packed trichomes (tr.) or hairs. (B) Bruguiera caryophylloides, showing structures as indicated in (A); note lack of trichomes on lower surface which, instead, is covered by a cuticle 

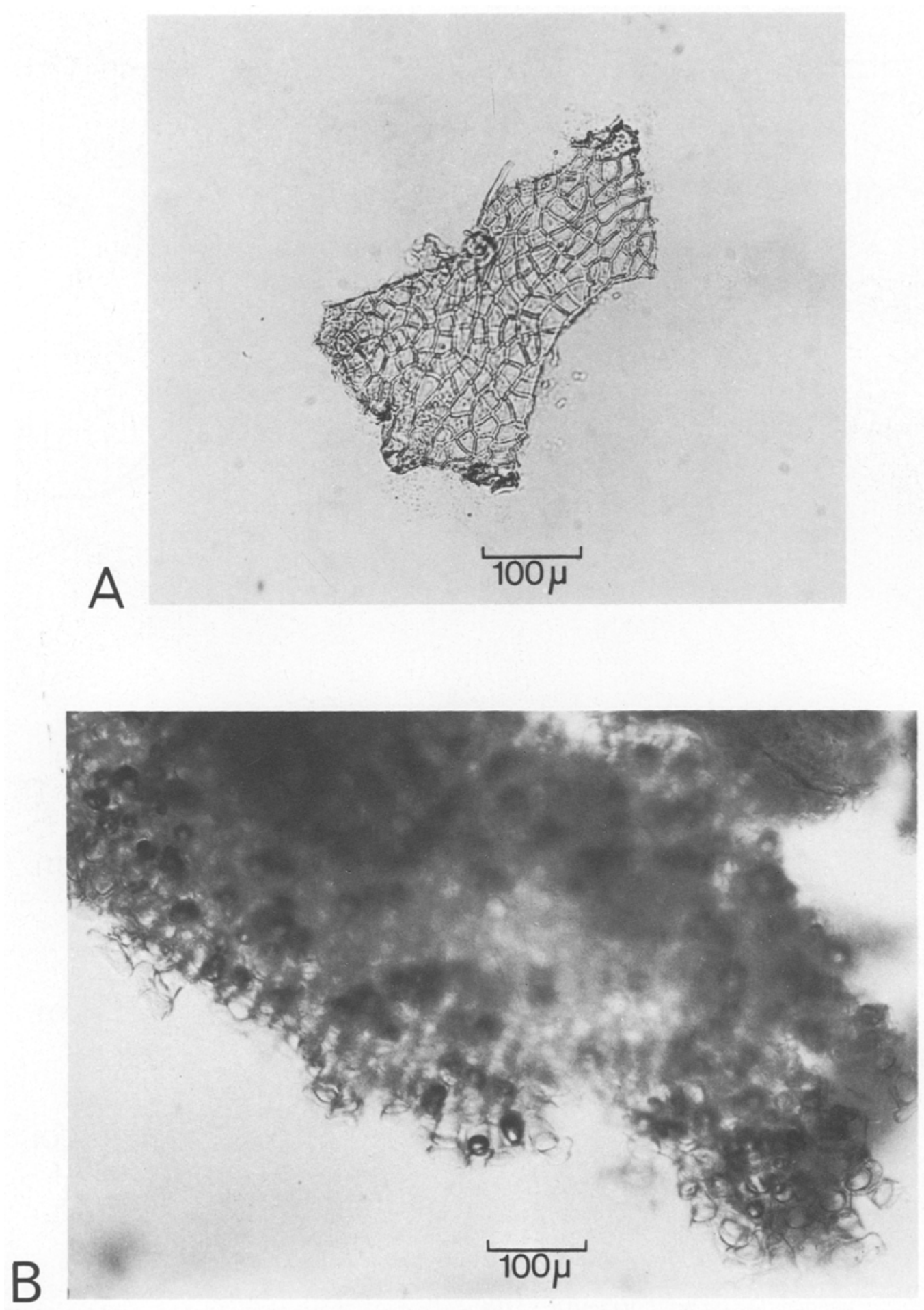

Fig. 3. Photomicrographs of unstained leaf fragments from proventriculus of Chiromanthes onychophorum. (A) leaf epidermis in plane view; (B) mesophyll from Avicennia intermedia bearing characteristic trichomes or hairs; (C) leaf vascular tissue; (D) degraded leaf particles; (E) detached trichome or hair from leaf of $A$. intermedia. 


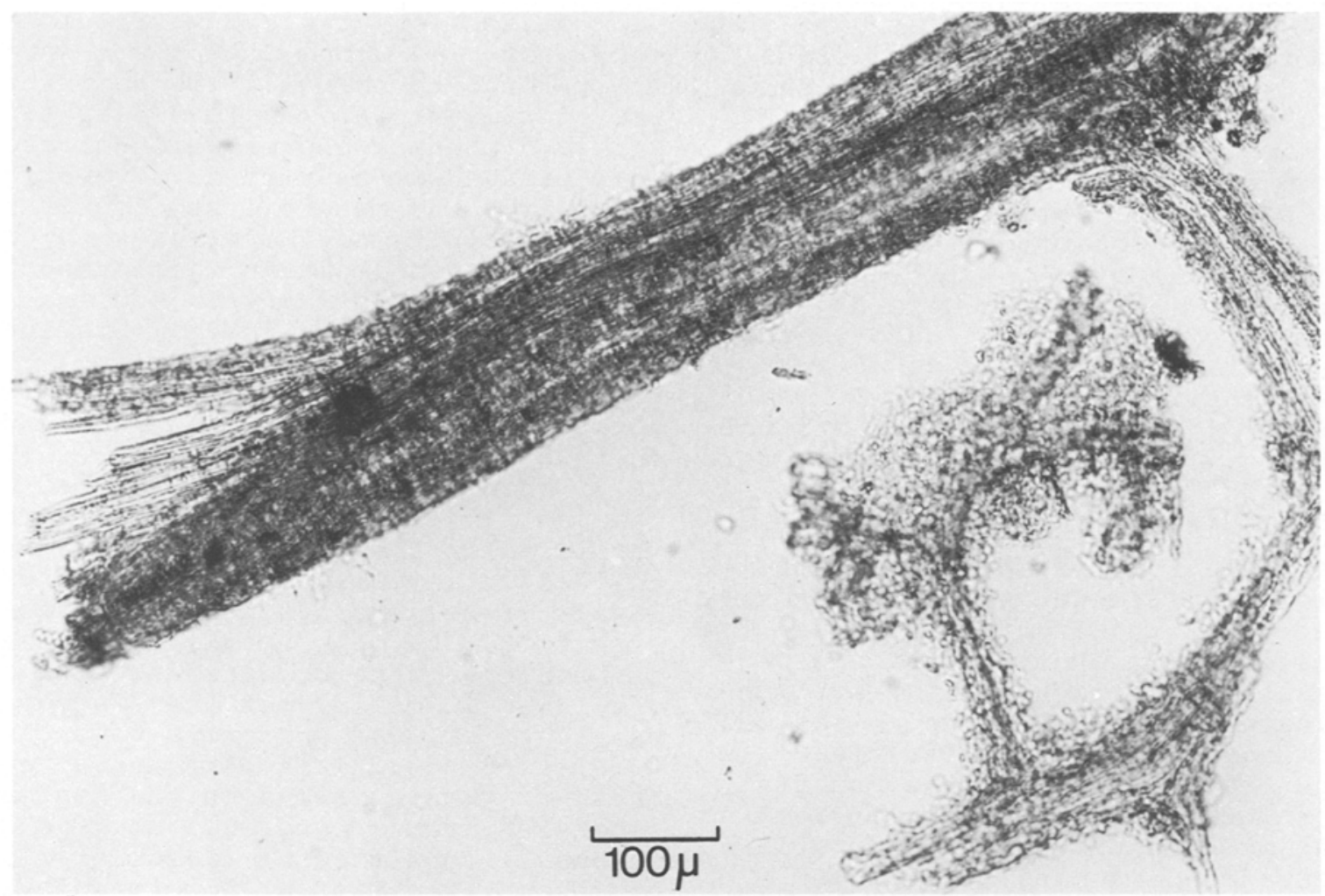

C

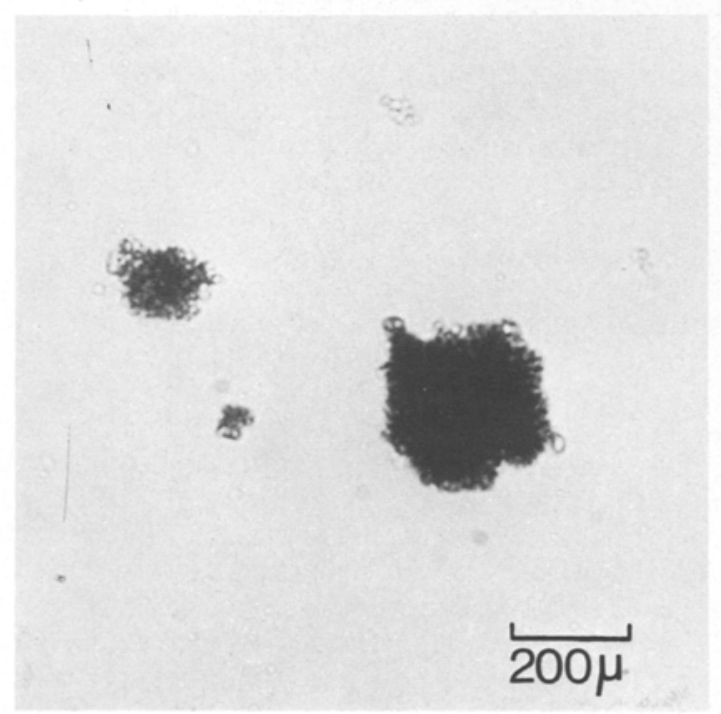

D

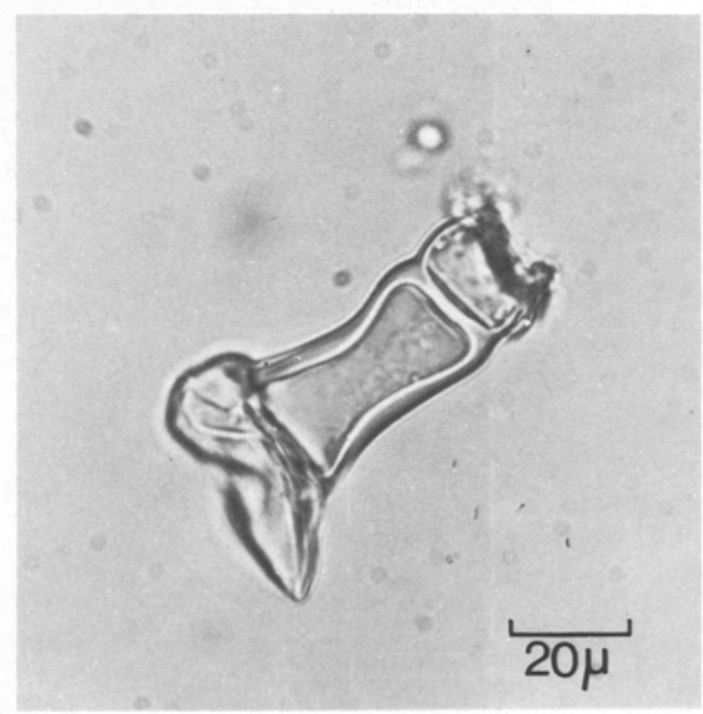

E

Fig. 3 (continued) 
Microscopical Analyses

The proventriculus or stomach, including cardiac and pyloric chambers (after Bullough, 1962), and abdominal hindgut including the rectum of preserved crabs were slit open and the contents washed out with and stored in $70 \%$ ethanol. Preserved samples of mud were washed through a $62 \mu \mathrm{m}$ mesh sieve with water, and the collected particles were stored in $70 \%$ ethanol. For comparison with gut contents, leaves of Avicennia intermedia and Bruguiera caryophylloides were digested in an equal mixture of $10 \%$ chromic acid and $10 \%$ nitric acid for 12 to $48 \mathrm{~h}$ at $60^{\circ} \mathrm{C}$, washed with water, then with saturated $\mathrm{NaHCO}_{3}$, and stored in $70 \%$ ethanol. In addition, leaves of both species were sectioned for light microscopy and stained with safranin and light green.

Identification and measurement of particles from the gut samples was carried out under the light microscope. The material in the proventriculus and rectum was divided into 8 categories: mangrove-leaf epidermis, mangrove-leaf mesophyl1, mangrove-leaf vascular tissue, degraded leaf particles, fine material, a silt and clay fraction, animal remains and diatoms, and unidentified material. Representative examples were photographed using Plus-X Pan film. Proportions of different categories of materials comprising the proventricular and hindgut contents were estimated under a dissecting microscope at $40 x$ magnification. Gut contents were evenly distributed over the bottom of a $10 \mathrm{~cm}$ Petri dish, and 10 fields of view were selected at random. In each field of view, the percentage of the total volume visible contributed by each of the 8 categories of particles was estimated. These ten percentages for each category were averaged for each crab.

The material present in the proventriculus of Chiromanthes onychophorum was analyzed for indication of the food items in the diet, and these contents were compared with those of the rectum and abdominal portion of the hindgut to observe the degree of processing by the crabs of the leaf material they consume.

\section{Determination of Organic Matter Content}

Samples of mud, proventricular and rectal contents were dried at $100^{\circ} \mathrm{C}$ for $24 \mathrm{~h}$ to obtain dry weight. Then they were ashed at $550^{\circ} \mathrm{C}$ in a muffle furnace for $6 \mathrm{~h}$. Organic matter content, measured as weight loss after ashing, was expressed as a percentage of dry weight.
Results

\section{Nature of Gut Contents}

Upon dissection, the proventriculus and rectum of Chiromanthes onychophorum were normally found to be full. The dominant material present was mangrove-leaf tissue. Bark and pneumatophores were not seen. Leaf tissue was assumed to have originated from the mangrove species present in the vicinity of the crabs when collected. Leaves from the 2 tree species present, Avicennia intermedia and Bruguiera caryophylloides, can be readily distinguished by the presence of closelypacked hairs or trichomes on the lower surface of $A$. intermedia (Fig. 2A) and their absence in B. caryophylloides (Fig. 2B). These trichomes are described by Chapman (1944) and Macnae (1968). The particles in the gut contents, defined as leaf epidermis, were comprised of sheets of cells polygonal in surface view (Fig. 3A). The epidermis of leaves of both tree species consists of a single layer of cells, but the fragments appeared to be leaf epidermis plus one or two layers of adhering hypodermal cells. These fragments varied in the longest dimension from 100 to $1600 \mu \mathrm{m}$. The leaf mesophyl1 consisted of irregular masses of mesophyllic tissue. Some mesophyll fragments bore the epidermal hairs characteristic of $A$. intermedia (Fig. 3B). This category of particles ranged from 100 to $2300 \mu \mathrm{m}$ in the longest dimension. Leaf vascular tissue was composed of the remnants of veins and xylem elements, the latter being identified by the spiral or ringed thickenings (Fig. $3 \mathrm{C}$ ). The length of these particles varied from 100 to $1800 \mathrm{\mu m}$.

Although many fragments of epidermis, mesophyll and vascular tissue in the gut contents were not identifiable to species, a substantial portion of the mesophyllic tissue bore the hairs characteristic of Avicennia intermedia. Also, numerous detached hairs were found in all stomach and rectal samples. Thus, these crabs appear to consume predominantly $A$. intermedia leaf material, and possibly also eat leaf material from Bruguiera caryophylloides, but the relative proportions of the two species in the gut contents was not determined in this study.

Degraded leaf particles were between 100 and $500 \mu \mathrm{m}$ in longest dimension (Fig. 3D). These particles could not be categorized as vascular, mesophyllic or epidermal because they were too far degraded. Mean length of 24 of these particles measured from rectal contents was $269.1 \mu \mathrm{m} \pm 21.6$ standard error (Table 1 ), significantly smaller than leaf epider- 
mal particles $(0.01<\mathrm{P}<0.05)$, leaf mesophyllic particles, and leaf vascular particles ( $P<0.01)$ from the same contents.

Fine material was defined as particles below $70 \mu \mathrm{m}$ in size. Most particles in this category were below $20 \mathrm{\mu m}$. For example, mean size of 11 fine-material particles was $12.61 \mathrm{\mu m} \pm 2.10$ standard error. Detached hairs from Avicennia intermedia, averaging $56.8 \mu \mathrm{m} \pm 2.7 \mathrm{SE}(N=31)$ and mostly between 40 and $70 \mu \mathrm{m}$, were included in this category (Fig. $3 E$ ).

The silt and clay fraction consisted of inorganic particles. Silts are defined as particles between 62.5 and 13.6 $\mu \mathrm{m}$ in diameter; clay between 13.6 and $0.12 \mu \mathrm{m}$ in diameter (Sverdrup et al., 1954). The inorganic particles in the gut contents were predominantly clays.

Animal remains and diatoms contributed little to the gut contents and were arbitrarily lumped together. Diatoms were present in the stomach whole or in pieces. The animal component included whole nematodes, bivalve shell fragments, and crustacean parts. Unidentified material may have been bacterial colonies, fungi or plant fruiting bodies.

\section{Proportions of Material in the Gut}

Analysis of the gut contents of 15 individuals of chiromanthes onychophorum is presented in Table 1 and Fig. 4. These data show that $79 \%$ of the material in the proventriculus of this species was recognizable mangrove leaf tissue. An additional 16\% was degraded leaf particles, presumably derived from mangrove leaf tissue, bringing the total to 95\%. Mangrove leaf material was thus the major food item for this species. Diatoms, invertebrates such as bivalves, nematodes and other crustaceans were either taken in small quantities or ingested incidentally with the leaf material.

The principal difference between proventricular and hindgut contents is clearly seen in Fig. 4 as an increase in the proportion of hindgut contents classed as degraded leaf particles. The hindgut contained $52 \%$ of this category compared with $16 \%$ in the proventriculus. This proportional increase was principally at the expense of the mesophyll, which decreased from $43 \%$ in the proventriculus to $9 \%$ in the hindgut. Vascular and epidermal tissue did not appreciably change in their percentage contribution. Nor did the contribution of the remaining four categories change.

Average lengths of several categories of particles in proventriculus and hindgut are given in Table 1. Particles of epidermis and mesophyll were not statistically different in length between the proventriculus and hindgut $(P>0.05)$ but vascular particles were longer in the rectum than in the proventriculus 10.01 $<\mathrm{P}<0.05)$. However, there was a reduction in overall average particle size by the time the undigested material was packaged into fecal pellets, since more of the particles in the hindgut were degraded leaf particles which were on the average smaller than the other three leaf categories. Thus, leaf material ingested by Chiromanthes onychophorum is incompletely digested and a large proportion of it is released back into the environment in a more finely-divided state than when it was ingested.

\section{Comparison of Dietary Organic Matter Content with that of Surrounding Mud}

To obtain an indication of the degree to which Chiromanthes onychophorum selects food items from material or organisms avail-

Table 1. Chiromanthes onychophorum. Percentages of total volume contributed by 8 categories of material in proventricular and rectal contents. Percentages averaged over 15 crabs and ranges are given. Lengths are means \pm standard exrors of several types of particles from proventriculus and rectum measured along their longest dimension, in $\mu \mathrm{m}$. $N=$ number of particles measured. epi: leaf epidermis; meso: leaf mesophyll; vasc: leaf vascular tissue; degr: degraded leaf particles; fine: fine material; $s+c l$ : silt and clay; anim: animal remains and diatoms; unident: unidentified material

\begin{tabular}{|c|c|c|c|c|c|c|c|c|}
\hline Portion of gut & epi & meso & vasc & degr & fine & $s+c l$ & anim & unident \\
\hline \multicolumn{9}{|l|}{ Proventriculus } \\
\hline$\frac{q}{8}$ & 19.3 & 43.2 & 16.7 & 15.9 & 3.8 & 0.4 & 0.3 & 0.4 \\
\hline Range & $6.9-43.4$ & $23.5-53.5$ & $10.0-27.6$ & $6.4-25.2$ & $2.0-5.8$ & $0.2-0.6$ & $0-4.0$ & $0-1.6$ \\
\hline $\begin{array}{l}\text { Length } \\
N\end{array}$ & $\begin{array}{l}421.6 \pm 23.8 \\
111\end{array}$ & $\begin{array}{l}672.0 \pm 30.5 \\
79\end{array}$ & $\begin{array}{l}598.6 \pm 32.0 \\
113\end{array}$ & & & & & \\
\hline \multicolumn{9}{|l|}{ Rectum } \\
\hline s & 16.0 & 9.4 & 18.3 & 52.5 & 2.4 & 0.3 & 0.2 & 0.9 \\
\hline Range & $4.8-28.1$ & $2.4-22.5$ & $7.4-31.6$ & $38.0-82.6$ & $0.5-4.9$ & $0.2-0.5$ & $0-2.8$ & $0-3.0$ \\
\hline Length & $451.6 \pm 79.9$ & $776.9 \pm 92.6$ & $791.1 \pm 72.0$ & $269.1 \pm 21.6$ & & & & \\
\hline$N$ & 18 & 26 & 21 & 24 & & & & \\
\hline
\end{tabular}




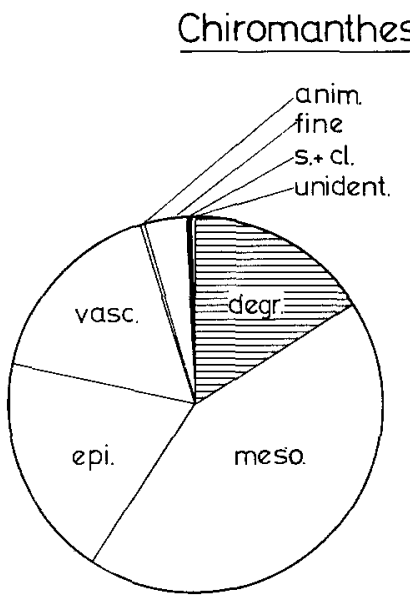

\section{onychophorum}

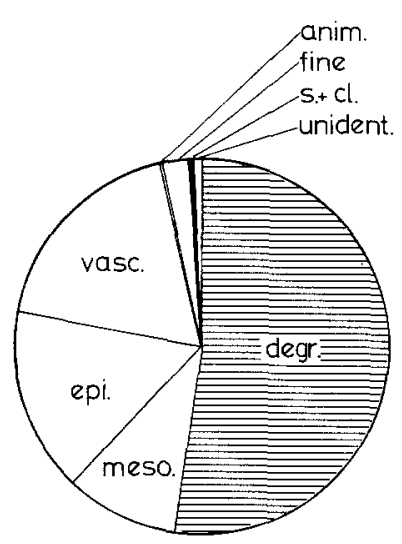

Stomach Contents

\section{Rectal Contents}

Fig. 4. Chiromanthes onychophorum. Percentage of total volume represented by 8 categories of material in stomach (proventricular) and rectal contents. $3.6^{\circ}=1 \%$. For explanation of abbreviations, see Table 1

Table 2. Percentage of organic matter in gut contents of Chiromanthes onychophorum and in mud collected at same time as crabs. $N$ : sample number

\begin{tabular}{|c|c|c|}
\hline & $\begin{array}{l}\text { Organic matter } \\
\text { weight } \pm \text { SE } \\
\text { Site } 2 \text { (mature } \\
\text { Avicennia in- } \\
\text { termedia) }\end{array}$ & $\begin{array}{l}\text { as }: \text { dry } \\
\text { Site } 3 \\
\text { (nipa zone) }\end{array}$ \\
\hline $\begin{array}{l}\text { Mud } \\
N\end{array}$ & $\begin{array}{l}19.5 \pm 0.7 \\
20\end{array}$ & $\begin{array}{l}13.7 \pm 0.8 \\
20\end{array}$ \\
\hline $\begin{array}{l}\text { Proventriculax } \\
\text { contents } \\
N\end{array}$ & $\begin{array}{l}89.0 \pm 2.4 \\
9\end{array}$ & $\begin{array}{l}79.8 \pm 3.5 \\
1.4\end{array}$ \\
\hline $\begin{array}{l}\text { Rectal contents } \\
N\end{array}$ & $\begin{array}{l}70.0 \pm 3.9 \\
5\end{array}$ & $\begin{array}{l}58.6 \pm 4.1 \\
7\end{array}$ \\
\hline
\end{tabular}

able on the mud surface, gut contents were compared with samples of the upper few millimeters of mud with respect to organic matter content. Surface mud from Collection sites 2 and 3 contained 14 to $20 \%$ organic matter, whereas the proventricular contents of the crabs comprised 80 to $90 \%$ organic matter (Table 2).

\section{Discussion}

This paper documents that the sesarmid crab Chiromanthes onychophorum, common in a Malaysian mangrove swamp, is a vegetarian, the contents of the proventriculus and rectum consisting, by volume, of more than 95\% mangrove leaf material. Consistent with this is the high proportion of organic matter in the proventricular contents compared with that of the

surrounding mud. Clearly, the crabs are not merely engulfing mud and digesting the organic matter. Although $C$. onychophorum was not observed feeding in the field, the following support the conclusion that leaf material is consumed as litter rather than by grazing on living mangrove trees. C. onychophorum is strictly an inhabitant of the swamp floor, in which it constructs burrows, and not a climber of trees (personal observation). Further, when $C$. onychophorum in the laboratory was fed green Avicennia intermedia leaves taken directly from trees, the gut contents appeared green (unpublished data), whereas gut contents of crabs from the field are brown. Whole nematodes and shell fragments of molluscs and crustaceans appeared in small quantities in the gut in addition to leaf material. Although analyses of gut contents may not give an accurate indication of proportions of food items consumed, since items appear in inverse relation to their digestibility, the proportion of macrofaunal remains in $C$. onychophorum guts was too low to consider them to be of nutritional significance.

It is necessary to consider whether Chiromanthes onychophorum reduces mangrove leaves or fragments from large pieces or consumes particles already of detrital size. Lenz. (1972) defines the upper size limit of detritus as $1 \mathrm{~mm}$, a functional definition based on the observation that organic material below this size tends to remain suspended in water and thus can be swept out of marshes or swamps whereas larger particles tend to settle out readily. The data in Table 1 indicate that the proventriculus is a site of particle size reduction, since much of the material in the proventriculus (i.e., mesophyll measuring 100 to 1600 $\mu \mathrm{m}$ in longest dimension) becomes reduced by the time it leaves that organ to degraded leaf particles, defined in this study as between 100 and 500 , $\mu \mathrm{m}$ in longest dimension, which comprised the bulk of the rectal contents. Even if $c$. onychophorum consumed particles of the size seen in the proventriculus, it qualifies predominantly as a leaf-breakdown agent and not a consumer of detritus. However, a number of factors suggest that the size of litter consumed is considerably larger than that seen in the proventriculus. By the time ingested leaf material is examined in the proventriculus it has been subject to fragmentation by the chelipeds, the mandibles, the gastric mill and to enzymatic digestion. Further, the chelipeds of this species are adapted for grasping and tearing, not for scooping as would be expected if the food were fine particles. 
Lastly, in the laboratory this species will readily feed upon whole Avicennia intermedia leaves and produce fecal pellets containing predominantly degraded leaf particles (own unpublished data).

Further study is necessary to indicate how important sesarmids such as Chiromanthes onychophorum are to the breakdown of mangrove leaf litter in the swamp. Estimates are needed of the rate of leaf fall, of the rate of consumption of leaf litter by an individual crab, and of the numbers of crabs per unit area of swamp. In addition, as discussed by Malley (1977), one needs to know the state of the leaf litter consumed by $c$. onychophorum, whether it may be freshly fallen or must be partially processed by other agents, such as microbes, before becoming palatable.

Breakdown of rooted marine plants to detritus is frequently a lengthy process involving a number of sequential agents (Fenchel, 1970; Heald, 1971). This study indicates that Chiromanthes onychophorum has the ability to convert mangrove leaves to small particles during a single passage through the gut. Although there are apparently a number of agents and pathways of leaf breakdown in tropical mangrove swamps such as snails and fungi, the abundance of these crabs and their efficiency at breakdown may partly explain the rapid rates of leaf-litter degradation on the floor of this Malaysian swamp (Mathias, 1975) compared with

those found in the Florida (USA) swamps where the principal macrofaunal agents of breakdown are amphipods (Heald, 1971). High tropical temperatures are most probably an important factor as well in the more rapid leaf breakdown.

Study of the feeding habits of common sesarmids consuming litter of various mangrove species in various swamp zones may well yield considerable information on the types of mangrove swamps, zones, age structures, etc., which are most favorable for the production of plant detritus and which, therefore, may be linked most closely to secondary production in offshore areas.

Acknowledgements. During this study the author was supported by Ford Foundation Grant No. 710-0562 to the University of Michigan. The author gratefully acknowledges the provision of research facilities and support for this study by the Dean, Professor C.P. Ramachandran, and the School of Biological Sciences, University of Science of Malaysia, where the author was a visiting faculty member. Dr. C.H. Wong was consulted for an understanding of mangrove plant anatomy. Technical assistance was expertly provided by S.R. Kalia and K.G. Goh. Histological sectioning was done by P.K. Chong.

\section{Literature Cited}

Berry, A.J.: The natural history of west Malaysian mangrove faunas. Malay. Nat. J. 25, 135162 (1972)

Bullough, w.s.: Practical invertebrate anatomy, $483 \mathrm{pp}$. London: Macmillan 1962

Chapman, V.J.: 1939 Cambridge University Expedition to Jamaica - Part 3. The morphology of Avicennia nitida Jacq. and the function of its pneumatophores. J. Iinn. Soc. (Bot.) 52, 487-533 (1944)

Darnell, R.M.: The organic detritus problem. In: Estuaries, pp 374-375. Ed. by G.H. Lauff. Washington, D.C.: American Association for the Advancement of Science 1967a. (Publs Am. Ass. Advmt Sci. No. 83)

- Organic detritus in relation to the estuarine ecosystem. In: Estuaries, pp 376-382. Ed. by G.H. Lauff. Washington, D.C.: American Association for the Advancement of Science 1967b. (Publs Am. Ass. Advmt Sci. No. 83)

Fenchel, T.: Studies on the decomposition of organic detritus from the turtle grass Thalassia testudinum. Limnol. Oceanogr. 15, 14-20 (1970)

Golley, F.B., H.T. Odum and R.F. Wilson: The structure and metabolism of a Puerto Rican red mangrove forest in May. Ecology 43, 9-19 (1962)

Heald, E.J.: The production of organic detritus in a South Florida estuary. Tech. Bull. Sea Grant Progm. Univ. Miami 6, 1-110 (1971)

Lenz, J.: The size distribution of particles in marine detritus. Memorie Ist. ital. Idrobiol. 29 (Suppl.), 17-35 (1972)

Macnae, W.: A general account of the fauna and flora of mangrove swamps and forests in the Indo-West-Pacific region. Adv. mar. Biol. 6, 73-270 (1968)

Malley, D.F.: Adaptations of decapod crustaceans to life in mangrove swamps. Mar. Res. Indonesia $18,63-72$ (1977)

Mann, K.H.: Macrophyte production and detritus food chains in coastal waters. Memorie Ist. ital. Idrobiol. 29 (Suppl.), 353-383 (1972a)

- Ecological energetics of the sea-weed zone in a marine bay on the Atlantic coast of Canada. II. Productivity of the seaweeds. Mar. Biol. 14, 199-209 (1972b)

Mathias, J.A.: Malaysian mangrove swamps: leaf litter breakdown and estuarine productivity. Abstracts of papers submitted for the $38 \mathrm{th}$ Annual Meeting of the American Society of Iimnology and Oceanography, Halifax; June 2226 (1975). (Copies available from Society at: Atmospheric and Oceanic Science, University of Michigan, 2455 Hayward, Ann Arbor, Michigan 48109, USA)

odum, E.P. and A.A. de la Cruz: Particulate organic detritus in a Georgia salt marshestuarine ecosystem. In: Estuaries, pp 383388. Ed. by G.H. Lauff. Washington, D.C.: American Association for the Advancement of Science 1967. (Publs Am. Ass. Advmt Sci. No. 83) 
Odum, W.E.: Pathways of energy flow in a South Florida estuary. Tech. Bull. Sea Grant Progm. Univ. Miami 7, 1-162 (1971)

Serene, R. and C.L. Soh: New Indo-Pacific genera allied to Sesarma Say 1817 (Brachyura, Decapoda, Crustacea). Treubia 27, 387-416 (1970)

Sverdrup, H.U., M.W. Johnson and R.H. Fleming: The oceans: their physics, chemistry, and general biology, 1087 pp. Englewood Cliff, N.J.: Prentice-Hall 1954

Teal, J.M.: Energy flow in the salt marsh ecosystem of Georgia. Ecology 43, 614-624 (1962)
Walsh, G.E.: Mangroves: a review. In: Ecology of halophytes, pp 51-174. Ed. by R. Reimhold and W. Queen. New York: Academic Press 1974

Watson, J.G.: Mangrove forests of the Malay Peninsula. Malay. Forest Rec. 6, 1-275 (1928)

Dr. D.F. Malley

Department of Fisheries and Oceans

Freshwater Institute

501 University Crescent

Winnipeg, Manitoba R3T 2N6

Canada

Date of final manuscript acceptance: July 14, 1978. Communicated by T. Platt, Dartmouth 